\title{
RNA and Protein Actors in X-Chromosome Inactivation
}

\author{
O. MASUI AND E. HeARD \\ CNRS UMR 218, Institut Curie, Paris 75005, France
}

\begin{abstract}
In female mammals, one of the two $\mathrm{X}$ chromosomes is converted from the active euchromatic state into inactive heterochromatin during early embryonic development. This process, known as X-chromosome inactivation, results in the transcriptional silencing of over a thousand genes and ensures dosage compensation between the sexes. Here, we discuss the possible mechanisms of action of the Xist transcript, a remarkable noncoding RNA that triggers the X-inactivation process and also seems to participate in setting up the epigenetic marks that provide the cellular memory of the inactive state. So far, no functional protein partners have been identified for Xist RNA, but different lines of evidence suggest that it may act at multiple levels, including nuclear compartmentalization, chromatin modulation, and recruitment of Polycomb group proteins.
\end{abstract}

The inactive X chromosome, or "Barr body," was first identified over 50 years ago as a heteropycnotic structure, only present in female somatic cells (Barr and Bertram 1949; Ohno and Hauschka 1960). Mary Lyon then published her seminal paper in 1961 making the link between this structure and the genetic inactivity of one of the two $\mathrm{X}$ chromosomes in females (Lyon 1961). She further proposed that this must be an early developmental event, which is then inherited mitotically, in order to explain the large patches of coat color mosaicism observed in female mammals heterozygous for X-linked genes.

$\mathrm{X}$ inactivation represents a powerful model system for studying mammalian epigenetics, as it involves differential regulation of two homologous chromosomes within the same nucleus, in a mitotically heritable but developmentally reversible manner. In placental mammals, X inactivation is initiated by a master control locus, the Xinactivation center (Xic), and the noncoding Xist transcript it produces. Xist RNA accumulates over the chromosome from which it is produced and is responsible for inducing cis-limited silencing of the $>1000$ genes on the X chromosome (Penny et al. 1996; Marahrens et al. 1998; Wutz and Jaenisch 2000). Since Xist was discovered in 1990, it has been the object of intense investigation; however, its regulation and its mechanism of action as a functional RNA still remain largely mysterious. Furthermore, the manner by which this silencing signal is transformed into the stable, transcriptionally repressed state that characterizes the inactive $\mathrm{X}$ chromosome is still poorly understood. However, several epigenetic marks, including histone modifications, Polycomb group proteins, and DNA methylation, are clearly important for the maintenance of the inactive state. Here, we summarize recent findings suggesting that Xist RNA may have multiple functions in the $\mathrm{X}$-inactivation process: in the recruitment of chromatin modifiers such as Polycomb group proteins and also at the level of nuclear compartmentalization. We describe data showing that Xist RNA may participate in the formation of a silent nuclear compartment into which $\mathrm{X}$-linked genes are recruited when they become inactivated. Spatial segregation from nucleoplasmic transcription factors of the X chromosome to be inactivated may thus represent a strategy, in addition to chromatin marks, for allowing the differential treatment of the two X chromosomes within the same nucleus. These findings also provide new insights into the structure and sequence organization of the cytologically defined Barr body. We also discuss another level at which RNA may function during the $\mathrm{X}$-inactivation process, which is for the recruitment of Polycomb group proteins to the inactive $\mathrm{X}$ chromosome. These proteins are involved in the maintenance of the inactive state, although the degree to which they are required for $\mathrm{X}$ chromosome inactivity may vary between lineages. Both PRC2 and $\mathrm{PRC} 1$ complexes appear to associate with the inactive $\mathrm{X}$ chromosome. The mechanisms employed for targeting these Polycomb complexes to the inactive $\mathrm{X}$ chromosome are only just beginning to be unraveled and appear to involve multiple strategies, including both histone modifications and RNA components. The inactive $\mathrm{X}$ chromosome thus provides, more than ever before, a useful model system for studying the interplay between nuclear organization, chromatin, RNA, and epigenetics.

\section{DEVELOPMENTAL TIMING OF XIST ACTION}

The early onset of Xist expression during development is consistent with its role in initiating $\mathrm{X}$ inactivation (Kay et al. 1993). In mice, there are two waves of X inactivation. The first is subject to imprinting and the second is random. During preimplantation development, the paternal Xist allele is expressed from the 2-cell stage, around the time of major zygotic genome activation. The maternal Xist allele remains inactive throughout this period due to a repressive imprint, the nature of which remains unknown, that is established in the maternal germ line (Tada et al. 2000). The early expression of the paternal Xist gene results in the inactivation of the paternal X chromosome from the 8-cell stage onward (Mak et al. 2004; Okamoto et al. 2004, 2005). Xist is essential for imprinted $X$ inactivation, as demonstrated by the early lethality of mouse embryos with a paternally inherited deletion of the gene (Marahrens et al. 1997). The inactivity of the paternal $X$ chromosome that is initiated in cleavage stages is maintained in extraembry- 
onic lineages such as the trophectoderm, but in the inner cell mass of the blastocyst the paternal $\mathrm{X}$ is reactivated (between 3.5 and 4.5 days postcoitum [dpc]). By this stage, the repressive maternal Xist imprint is also lost. In this way, when the second wave of $X$ inactivation initiates in the epiblast (around $5.5 \mathrm{dpc}$ ), either the paternal or maternal X chromosome will up-regulate Xist, and this triggers random $\mathrm{X}$ inactivation. Female embryonic stem (ES) cells, which are derived from the inner cell mass of blastocysts, represent a useful in vitro model system for X inactivation. Upon differentiation, Xist is up-regulated and accumulates on one of the two X chromosomes; this is followed by gene silencing and the appearance of a number of epigenetic marks (Fig. 1). Again, knockout studies have shown that Xist is essential for this random $\mathrm{X}$-inactivation process (Penny et al. 1996).

Although the timing of Xist expression and X inactivation pointed to an early time window for its function, the exact window in which it could act was defined in a series of elegant studies using ES cells carrying an inducible Xist cDNA transgene (Wutz and Jaenisch 2000). Xist RNA-dependent silencing could only be triggered during the first 48-72 hours of differentiation. This early time window for Xist action suggests either that chromatin is somehow rendered refractory to Xist RNA silencing as differentiation progresses, or alternatively, that Xist RNA requires the presence of a specific factor that is only present during early development for its silencing activity. During this early time window, the inactive $\mathrm{X}$ is fully reversible upon arrest of Xist expression. However, following 72 hours of differentiation and Xist expression, $\mathrm{X}$ inactivation can no longer be reversed if the inducible Xist cDNA is turned off (Wutz and Jaenisch 2000). Thus, some form of chromosomal memory must be established on the inactive $\mathrm{X}$ during differentiation (Kohlmaier et al. 2004). Some of the changes that could be involved in this chromosomal memory, and that are induced following Xist RNA coating of the X chromosome in differentiating female ES cells, include a shift to asynchronous replica-

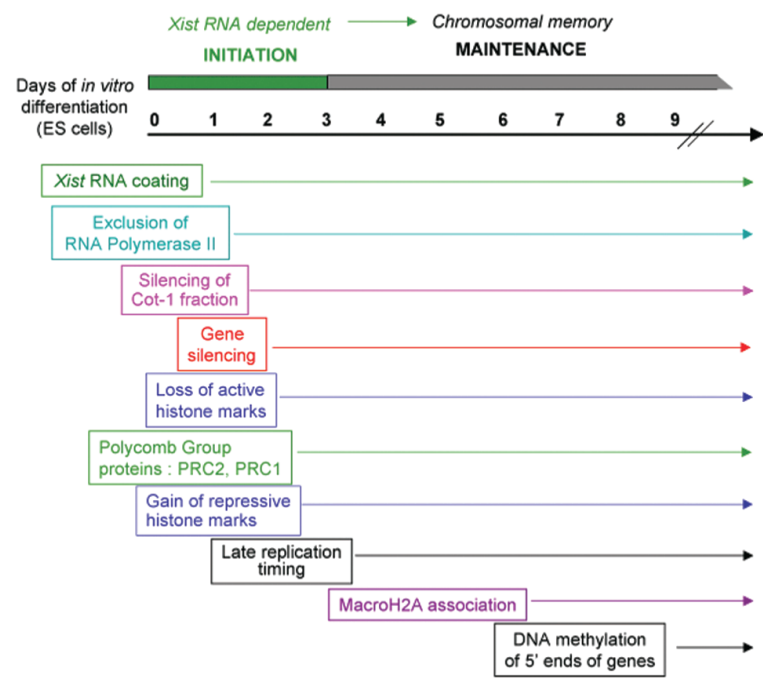

Figure 1. Kinetics of random XCI. The time of onset of different events during the onset of random $\mathrm{X}$ inactivation is shown. tion timing (Takagi et al. 1982), incorporation of the histone variant macro H2A (Mermoud et al. 1999; Costanzi et al. 2000), DNA (CpG) methylation (Norris et al. 1991), and a variety of histone modifications (Chaumeil et al. 2002; for review, see Heard 2004). In particular, changes in histone $\mathrm{H} 3$ and $\mathrm{H} 4$ modifications occur early on and include the loss of active, euchromatic marks such as H3K9 and H4 acetylation (Jeppesen and Turner 1993; Boggs et al. 1996; Keohane et al. 1996), as well as H3K4 di- and tri-methylation. These changes can be observed just one day after Xist RNA coating both in early mouse embryos at the 4- to 8-cell stage (Okamoto et al. 2004) and in differentiating ES cells at day 2. Marks generally associated with gene repression, such as the di-methylation of H3K9 (Heard et al. 2001; Boggs et al. 2002; Mermoud et al. 2002; Peters et al. 2002) and tri-methylation of H3K27 (Plath et al. 2003; Silva et al. 2003; Rougeulle et al. 2004), appear on the inactive $X$ at around day 2 of ES cell differentiation. In early mouse embryos, where the temporal resolution of events is more straightforward than in differentiating ES cells, the time of onset of the repressive (H3K27me3 and $\mathrm{H} 3 \mathrm{~K} 9 \mathrm{me} 2)$ marks occurs later ( $>16$-cell stage) than the loss of euchromatic histone marks on the paternal $\mathrm{X}$ chromosome. Polycomb group proteins associate with the inactive $\mathrm{X}$ chromosome during the same developmental time window as the acquisition of repressive histone marks and are responsible for some of the above histone modifications. For example, Ezh2 (PRC2 complex) is responsible for H3K27me3, and Ring 1a/b (PRC1 complex) is responsible for ubiquitination of H2AK119, as discussed below. The timing of appearance of Polycomb group proteins, following Xist RNA coating during early development (Mak et al. 2004; Okamoto et al. 2004), or after induction of an Xist cDNA (Plath et al. 2003; Kohlmeier et al. 2004), suggests that they could be recruited to the chromosome by Xist RNA itself, although this remains to be proven. However, rather than being involved in the initiation of silencing, as discussed below, these complexes may form part of the chromosomal memory of the inactive X chromosome. Thus, contrary to the initial belief that Xist RNA would only be involved in the initial silencing events of $\mathrm{X}$ inactivation, it now appears that it may also have a role in recruiting some of the early epigenetic marks that take over once silencing has occurred.

\section{FUNCTIONAL DOMAINS OF XIST RNA}

The functional Xist transcript is spliced, polyadenylated, and measures 17,000-19,000 nucleotides in length. Despite such features, which usually characterize messenger RNAs, it is retained in the nucleus and is untranslated. Although the overall structure of the Xist gene is well conserved between eutherian mammals, its sequence is remarkably poorly conserved, given its central function in controlling $\mathrm{X}$ inactivation. However, this is consistent with its presumed role at the RNA level and the fact that conservation may be mainly in its secondary or tertiary RNA structure, as opposed to its primary sequence. Furthermore, the most highly conserved regions in this transcript comprise a series of repeats (termed A-E, see 
Fig. 2A). The A repeats, located at the $5^{\prime}$ end of the first exon of Xist, are the most conserved of all. Indeed, these repeats were shown to be capable of inducing repression of $\mathrm{X}$-linked genes in an in vitro assay (Allaman-Pillet et al. 2000). To define the functional regions of the Xist transcript in vivo, male ES cells containing inducible Xist cDNAs with different deletions were tested for their capacity to induce silencing and chromosome coating in cis (Wutz et al. 2002). Because the inducible transgene was located on the single $\mathrm{X}$ chromosome in a male cell, $\mathrm{X}$ inactivation induced nullisomy. Cell death was thus used as an assay for the capacity of different Xist deletions to induce inactivation. In this way, the A repeats were shown to be the only region apparently critical for Xist's silencing function. A number of different regions of Xist RNA were shown to be involved in its capacity to coat a chromosome in cis, as well as its ability to recruit potential epigenetic marks described above, such as macroH2A and H3K27

A

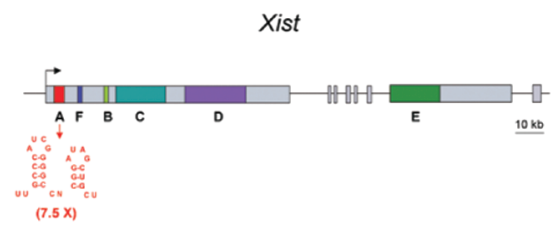

B

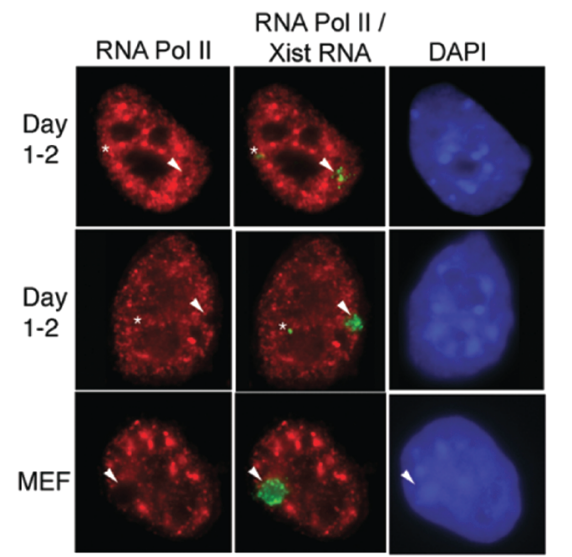

C

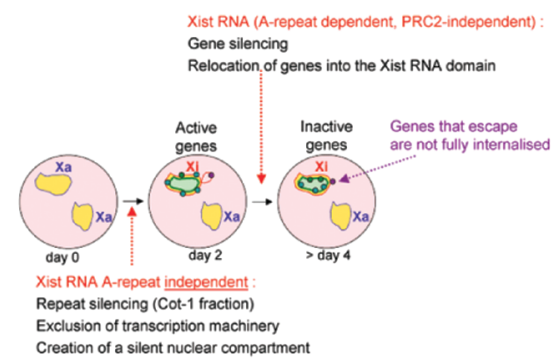

Figure 2. The Xist gene and it potential role in creating a silent nuclear compartment. (A) A map of the murine Xist gene is shown, indicating the conserved repeats $(\mathrm{A}-\mathrm{E})$. The sequence of the most highly conserved A repeats, involved in the gene silencing function of Xist, is shown. (B) Example of RNA polymerase II immunofluorescence combined with Xist RNA FISH in early differentiating ES cells (top two panels) and embryonic fibroblasts (lower panel). This shows overall exclusion of RNA pol II at the level of the domain of nuclear Xist RNA accumulation as described by Chaumeil et al. (2006). (C) Model for two types of Xist RNA function during the onset of X inactivation, based on Chaumeil et al. (2006). tri-methylation (Wutz et al. 2002; Plath et al. 2003; Kohlmaier et al. 2004). The fact that a Xist transcript, mutated for the A repeats and incapable of inducing gene silencing, can still recruit Polycomb group complexes and associated H3K27me3 and H2AK119 ubiquitination, demonstrates that these chromatin changes are not sufficient for the silencing function of Xist.

The molecular mechanisms that underlie Xist RNA's capacity to induce transcriptional silencing remain unclear. One possibility is that Xist RNA acts to change chromatin in order to induce the silent state. As mentioned above, Polycomb group proteins are unlikely to be involved in this initiation step. The rapid loss of active histone modifications ( $\mathrm{H} 3$ and $\mathrm{H} 4$ acetylation as well as H3K4 and H3K36 methylation) following Xist RNA coating (Chaumeil et al. 2002, 2006) suggests that Xist RNA may have a function in recruiting histone deacetylase and/or demethylase complexes. On the other hand, Xist RNA might recruit chromatin remodeling enzymes that result in the active ejection and replacement of "actively" marked histones by unmodified histones (which then become modified by Polycomb group complexes) or even histones with certain inactive marks. A role for histone variants (for example the H3.1, H3.2, and $\mathrm{H} 3.3$ forms of histone $\mathrm{H} 3$ ) in the initiation of silencing could also be possible, but so far remains unknown. Whether Xist RNA has a direct role in the loss of active histone marks, and whether this loss is a cause or consequence of gene silencing, are clearly areas that merit future investigation. Alternative models for Xist RNA's silencing function include the recruitment of a repressor protein or complex, although so far no such complex has been identified. Attempts to purify Xist A-repeat-specific partners identified hnRNPC (Brown and Baldry 1996), one of the most ubiquitous hnRNPs, although no link with $\mathrm{X}$ inactivation has yet been reported. Xist RNA may also recruit factors that induce other repressive histone marks such as $\mathrm{H} 3 \mathrm{~K} 9 \mathrm{me} 2$ and H4K20me1, which might be involved in initiation and/or maintenance of $\mathrm{X}$ inactivation. However, the modifying enzymes involved and their link with Xist RNA remain to be found. Finally, a longstanding hypothesis is that Xist RNA could participate in the formation of a silent nuclear compartment within which the $\mathrm{X}$ chromosome is silenced. Recent findings suggesting that Xist RNA may indeed function in this way are described in the next section.

\section{Xist RNA IN NUCLEAR COMPARTMENTALIZATION}

A possible architectural role for Xist RNA in creating a repressive nuclear compartment or structure around the $\mathrm{X}$ chromosome was proposed some years ago (Clemson et al. 1996). Xist RNA is intriguingly restricted in its nuclear localization to the vicinity of the chromosome territory from which it is expressed (Brown et al. 1992; Clemson et al. 1996). This restriction does not appear to be dependent on the DNA of the chromosome itself, as the appearance of the Xist RNA domain remains unperturbed after DNase treatment (Clemson et al. 1996). It has therefore been proposed that Xist RNA may show only an indirect 
association with the $\mathrm{X}$ chromosome and a closer association with the nuclear matrix. Potential support for this has come from the finding that scaffold attachment factor A (SAF-A) is enriched on the inactive $\mathrm{X}$ chromosome in an RNA-dependent manner (Helbing and Fackelmayer 2003). Xist RNA might thus form a stable structure with nuclear matrix or scaffold factors, which could be important for initiation and/or maintenance of the inactive state (Fackelmayer 2005).

Our laboratory recently set out to determine whether Xist RNA might function at the level of nuclear organization, using differentiating ES cells to assess changes in nuclear organization relative to chromatin changes and gene silencing. We showed that Xist RNA chromosome coating leads to the rapid exclusion of RNA polymerase II and associated transcription factors (Fig. 2B). This represents the earliest event following Xist RNA accumulation described so far and precedes the loss of active histone marks such as $\mathrm{H} 3 \mathrm{~K} 9$ acetylation and $\mathrm{H} 3 \mathrm{~K} 4$ dimethylation (Chaumeil et al. 2006). Only subsequently do genes cease to be transcribed, as detected at the primary transcript level by RNA FISH, which allows the exact timing of transcriptional silencing to be assessed at the single-cell level. Similar findings were found in early mouse embryos: RNA pol II was found to be excluded from the Xist RNA-coated paternal X chromosome from the 4- to 8-cell stage in mouse embryos (Okamoto et al. 2004). We also found that the RNA pol II-excluded compartment within the Xist RNA accumulation is transcriptionally silent, as detected by RNA FISH using Cot-1 DNA as a probe, which detects middle repetitive elements. Although it has been reported that Cot-1 RNA detected in this way corresponds to transcribed repetitive elements present in introns, or 5' and $3^{\prime}$ UTRs of genes, we have so far not found any genic loci that lie within this Cot-1 hole at early differentiation stages (Chaumeil et al. 2006; J. Chow and E. Heard, unpubl.). Thus, the rapid RNA pol II exclusion and Cot-1 silencing induced by Xist RNA only seem to affect a repeat-rich fraction at the core of the X-chromosome territory. The exact nature of the sequences present within the silent Xist RNA compartment is currently under investigation.

On the other hand, X-linked genes, which are still active at early stages of differentiation (days 1-2), were always found to be located outside, or at the periphery of this Xist RNA domain and within the nucleoplasmic RNA pol II, as might be expected given their transcriptional activity. However, upon transcriptional silencing (by day 4), most genes were found to show a significant shift in position, to a location within the Xist RNA domain. The only loci that continued to show a more external location even at late differentiation stages were the Xist gene, which remains active on the otherwise inactive $X$, and Jarid1c, which escapes from $\mathrm{X}$ inactivation in approximately $50 \%$ of differentiated cells. The external location of these genes therefore appears to be linked to their transcriptional activity. We also made the very surprising observation that Xist RNA can trigger the exclusion of RNA pol II within the Xist RNA domain, even in the absence of the A-repeat silencing region of the Xist transcript. This was an unexpected finding, because the silencing function of Xist RNA was previously believed to be solely dependent on its A-repeat region (Wutz et al. 2002). Indeed, the A-repeat-deleted Xist transcript was found to be deficient in its capacity to trigger $\mathrm{X}$ inactivation at the level of all the X-linked genes examined. In this case, genes remain external to the Xist RNA domain and continue to be transcribed throughout differentiation. The formation of a Xist RNA compartment, depleted of transcription factors, is therefore not in itself sufficient to induce relocation and silencing of X-linked genes. However, the Cot-1 RNA fraction of the X chromosome that lies within the Xist RNA domain was found to be silenced in an Xist A-repeat-independent fashion. This implies that Xist RNA may exert different types of silencing function - one aimed at repeats and the other at genes.

This study provided the first evidence for a new and early step in the X-inactivation process. It also suggests a novel role for Xist RNA in the formation of a silent nuclear compartment which initially comprised the more repetitive part of the $\mathrm{X}$ chromosome (Fig. 2C). This new function for Xist RNA is independent of its A repeats and results in the rapid exclusion of the transcription machinery from the $\mathrm{X}$ chromosome chosen to be inactivated. Gene repression occurs subsequently, requires Xist A-repeat action, and is accompanied by a shift from outside to inside this silent nuclear compartment. This shift is not simply a consequence of increased Xist RNA coating or increased Xchromosome compaction, as we found that Xist RNA always coats approximately $70 \%$ of the volume of the $\mathrm{X}$ chromosome at all stages of differentiation examined. Rather, the onset of $\mathrm{X}$ inactivation is accompanied by a dynamic 3D reorganization of X-linked genes. Given that the movement of genes toward the interior of the transcriptionally inert Xist RNA domain does not precede gene silencing, but rather accompanies or follows it, one explanation is that the transcriptional repression induced by the Xist A repeat containing RNA results in the capacity of genes to become internalized. In some cases, actively transcribed genes have been shown to be located in putative "transcription factories" (see Osborne et al. 2004). When Xist A-repeat-induced silencing occurs, a gene may become unleashed from such a transcription compartment and thus become more internally located by default. An alternative but not mutually exclusive explanation for gene relocation could be that the Xist transcript, and the ribonucleoprotein structure it forms, participate in "reeling" genes into the silent domain, either through local chromatin condensation or through active translocation. The fact that genes do not undergo internalization in the Xist A-repeat mutant, despite the recruitment of Polycomb group proteins, suggests that these proteins are not sufficient to induce relocation, although they may still be necessary.

\section{REDEFINING THE BARR BODY}

Our studies have provided a novel perspective on the molecular content of the cytologically defined, heteropycnotic Barr body. Although the appearance of a DAPIdense structure at the level of the Xist RNA-coated X chromosome occurs early on in differentiation, our work suggests that this may in fact correspond to the silent, 
repetitive core of the X-chromosome territory that is confined within the Xist RNA domain, rather than to genes. All of the X-linked genes we have examined to date tend to be located on the more peripheral portion of the $\mathrm{X}$ chromosome territory (as determined by DNA FISH using a mouse X-chromosome paint), whatever their activity status, and the relocation of X-linked genes from outside to inside the Xist RNA compartment during $\mathrm{X}$ inactivation actually only entails a shift in position in the order of $0.1-0.8 \mu \mathrm{m}$. This is also the case for the human $\mathrm{X}$ chromosome, which has been shown to consist of a repetitive inner core, with genes located on its outer rim (Clemson et al. 2006). It is therefore very likely that the heteropycnotic structure originally identified by Barr in 1949 (Barr and Bertram 1949) in fact corresponds mainly to the repetitive core of the inactive X. Furthermore, our analysis of the Xist A-repeat mutants suggests that this heteropycnotic structure may form even in the absence of gene silencing. The implication of this is that studies over the decades which have assessed the presence of an inactive $\mathrm{X}$ chromosome only at the level of presence or absence of a Barr body need to be reconsidered, as transcriptional activity of genes and the formation of a Barr body may be separable events.

However, ultrastructural analyses of the inactive $\mathrm{X}$ chromosome, using electron microscopy, will be required to obtain a more detailed vision of its structure and the distribution of repeats versus genes. Furthermore, whether the repetitive core of the $\mathrm{X}$ chromosome contains any genes whatsoever remains to be found. It would be predicted that such genes, were they to exist, might be subject to very rapid silencing in an Xist A-repeat-independent fashion. Genes that remain located at the periphery of or outside the silent Xist RNA compartment throughout differentiation, such as the Jaridlc gene, may provide potential insights into the process of escape from $\mathrm{X}$ inactivation. The external location of the Jaridlc gene may reflect a resistance of this locus to be internalized, despite the silencing action of the Xist A repeats. This would be consistent with the recent finding that Jaridlc is flanked by CTCF boundary elements, which could render it more resistant to relocation compared to other genes (Filippova et al. 2005). Intriguingly, however, escape genes on the human inactive $\mathrm{X}$ chromosome do not appear to be more externally located, relative to the Xist RNA domain, than those genes that are subject to $\mathrm{X}$ inactivation (Clemson et al. 2006).

The regions of Xist RNA, other than the A repeats, that are capable of creating a silent nuclear compartment and heteropycnotic structure remain to be defined through the analysis of further Xist mutants. It is also not yet known whether the silent nuclear compartment created by Xist RNA represents a physical or biochemical entity. Although SAF-A interacts with the inactive X chromosome in somatic cells, this has not yet been demonstrated in differentiating ES cells, nor has any evidence for a direct interaction between Xist RNA and SAF-A been reported. Accessibility assays might address the extent to which Xist RNA and its protein partners might create a physical barrier to transcription factors. It is, however, unlikely that the exclusion of the transcription machinery by Xist RNA is a result of the recruitment of Polycomb group complexes to the $\mathrm{X}$, even though this is also an Xist A-repeat-independent function. Polycomb group complexes may, however, play a role in stabilizing the repressive environment created by Xist RNA, and it will be interesting to investigate the extent to which the silent nuclear compartment defined by Xist RNA is maintained in Polycomb group mutants.

\section{POLYCOMB GROUP PROTEINS IN X INACTIVATION}

\section{Background to the Function and Constitution of PcG Complexes}

Polycomb group (PcG) genes were first identified in Drosophila in the 1940s (for review, see Ringrose and Paro 2004). Mutations in PcG genes lead to perturbations in the maintenance of repression of homeotic genes, which are important for body segmentation. Misregulation of Hox genes induces severe developmental defects in flies, and this relationship between PcG genes and Hox genes is well conserved from Drosophila through to mammals. In mammals, however, PcG genes appear to be involved in numerous other processes, including stemcell renewal and differentiation, hematopoesis, cellular senescence, and X-chromosome inactivation. Indeed, although the PcG proteins are highly conserved throughout evolution, the homologs for each of the PcG genes in Drosophila are found to be expanded and to exist as gene families in mammals, which presumably confers their divergent roles (for review, see Gil et al. 2005). Both genetic and biochemical experiments have shown that most PcG proteins work in complexes that can be divided into two main classes, although these are fairly dynamic and can differ in their exact compositions (Otte and Kwaks 2003; Levine et al. 2004). One of these is termed Polycomb repressive complex 1 (PRC1) and the other is known as PRC2 (also called ESC-E(Z) complex or EEDEZH2 complex) (Fig. 3).

PRC1 was the first complex to be purified from Drosophila embryos (Shao et al. 1999; Saurin et al. 2001) and HeLa cells (Levine et al. 2002), and it represents a huge 1- to 2-MD protein complex with its core components being Pc, Ph, Psc, Scm, and Ring (see Fig. 3). These PRC1 proteins have multiple functions affecting chromatin structure (Levine et al. 2004), including a ubiquitin ligase activity for histone H2A K119 (Wang et al. 2004), mediated by Ring1b as the ubiquitin E3 ligase (de Napoles et al. 2004; Wang et al. 2004).

The second PcG protein complex, PRC2, was purified from both Drosophila embryos (Ng et al. 2000; Tie et al. 2001, 2003; Czermin et al. 2002; Müller et al. 2002) and mammalian cells (Cao et al. 2002; Kuzmichev et al. 2002) as an approximately $600-\mathrm{kD}$ complex and shown to contain Esc (Eed in mammals), Su(z)12 (Suz12 in mammals), and $\mathrm{E}(\mathrm{z})$ (Ezh2 in mammals) as core components (Fig. 3). The E(z)/Ezh2 protein contains a SET (Su-(var)3-9, E(z), Trithorax) domain and, consistent with other SET-domain proteins, it has a histone methyltransferase (HMTase) activity. In vitro studies have shown that $\mathrm{E}(\mathrm{z})$ acts to 


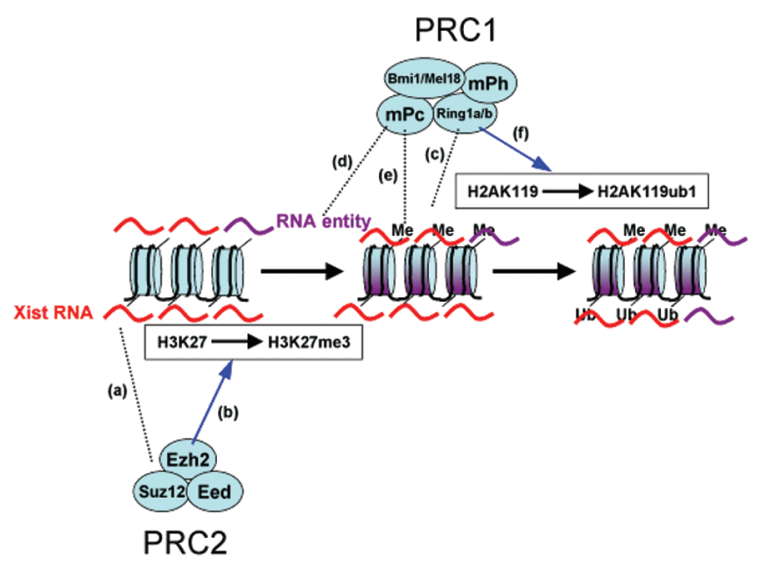

Figure 3. Schematic representation of Polycomb group complex proteins that associate with the Xist RNA-coated X chromosome. Possible relationships between PRC1/2 and chromatin changes on the inactive $\mathrm{X}$ chromosome are shown. Blue arrows indicate enzymatic activity for the reaction depicted by a black arrow in the rectangle. Broken lines indicate potential binding affinity. (a) Xist RNA leads to PRC2 complex recruitment through unknown mechanisms (Schoeftner et al. 2006); $(b)$ the PRC2 protein, Ezh2, catalyzes tri-methylation of histone $\mathrm{H} 3$ at lysine 27 (Kuzmichev et al. 2002). Both Eed and Suz12 are required to form a stable PRC2 complex and for the HMTase activity of Ezh2. (c) Ring1b protein is recruited by Xist RNA in a PRC2-independent manner (Schoeftner et al. 2006). (d) One of the murine Polycomb homologs, $\mathrm{Cbx} 7$, is retained on the inactive $\mathrm{X}$ chromosome in an RNA-dependent manner (Bernstein et al. 2006) and through binding to H3K27me3 for which it has a high affinity. (e) mPc proteins have affinity for $\mathrm{H} 3 \mathrm{~K} 27 \mathrm{me} 3$ (Bernstein et al. 2006). (f) Ring1a and Ring1b proteins catalyze mono-ubiquitylation of histone $\mathrm{H} 2 \mathrm{~A}$ at lysine 119 (de Napoles et al. 2004). Certain PRC1-associated proteins, such as Scm, have not so far been detected at the level of the inactive X chromosome, although their presence has not been formally excluded.

methylate histone $\mathrm{H} 3$ at $\mathrm{K} 9 / \mathrm{K} 27$ (Cao et al. 2002; Czermin et al. 2002; Kuzmichev et al. 2002; Müller et al. 2002) and histone H1at K26 (Kuzmichev et al. 2004). In vivo studies, involving Suz12 and Eed mutant embryos, confirm that Ezh2 is indeed responsible for H3K27 diand tri-methylation (Pasini et al. 2004; Kalantry et al. 2006). In mammals, PRC2 consists of at least Ezh2, Eed, Suz12, and RbAp48 (Cao et al. 2002; Kuzmichev et al. 2002). In addition, the Eed gene can produce several isoforms of the Eed protein that are used for different substrates and in different cellular situations (Kuzmichev et al. 2004, 2005). The core components of PRC2 appear to be crucial for the stability of the complex as well as its chromatin-associated activities. Ezh2 alone does not have HMTase activity and can only act in the presence of both Eed and Suz12 (Cao and Zhang 2004; Pasini et al. 2004). In fact, in the absence of Suz12, the Ezh2 protein appears to be highly unstable (Pasini et al. 2004).

The fundamental roles of the PRC2 complex in mammals are illustrated by the embryonic lethality that mutants for most of these proteins induce. For example, mouse mutants in Eed (Faust et al. 1995; Wang et al. 2001), Ezh2 (O'Carroll et al. 2001), and Suz12 (Pasini et al. 2004) have all been reported to show early developmental lethality, around $7.5 \mathrm{dpc}$.

\section{Evidence for a Role for PcG Complexes in $\mathrm{X}$ Inactivation}

Several lines of evidence suggest that $\mathrm{PcG}$ proteins are implicated in $\mathrm{X}$ inactivation. Circumstantial evidence comes from immunofluorescence studies. First, several components of PRC1 and PRC2 complexes have been shown to accumulate on the inactive $\mathrm{X}$ chromosome during early development and ES cell differentiation, following Xist RNA coating of the X chromosome (Mak et al. 2002; de Napoles et al. 2004; Plath et al. 2004). Second, two of the histone modifications associated with PcG function, H3K27me3 and H2AK119 mono-ubiquitylation (H2Aub1), become enriched on the inactive X during a similar time window (Mak et al. 2002; Silva et al. 2003; de Napoles et al. 2004; Plath et al. 2004). Genetic evidence for an involvement of $\mathrm{PcG}$ proteins in $\mathrm{X}$ inactivation first came from the analysis of $\mathrm{Eed}^{-1-}$ mutant mice (Wang et al. 2001). Female mutant mice carrying a GFP transgene on their paternally inherited $\mathrm{X}$ chromosome, which should be silent in extraembryonic tissues due to imprinted paternal $\mathrm{X}$ inactivation, showed a proportion of GFP-positive cells after $5.5 \mathrm{dpc}$. This result suggests that Eed mutant mice can initiate imprinted $\mathrm{X}$ inactivation, but cannot maintain it efficiently. No apparent effect was observed on the random X-inactivation process in the embryo-proper of $\mathrm{Eed}^{-/-}$mutants (Wang et al. 2001; Kalantry and Magnuson 2006), although a minor effect had been reported in one study (Silva et al. 2003). More recently, a conditional Eed knockout was generated in ES cells containing an inducible Xist cDNA, and the absence of Eed (and the resulting lack of Ezh2-mediated H3K27 methylation) was found to have no impact on either the initiation or the maintenance of Xist RNA-mediated silencing (Schoeftner et al. 2006). These findings are consistent with the data described above, showing that PRC2 is not involved in the initiation of $\mathrm{X}$ inactivation, as ES cells expressing the Xist transcript mutated for its A repeats are incapable of gene silencing, despite the recruitment of PRC2 and $\mathrm{H} 3 \mathrm{~K} 27 \mathrm{me} 3$ to the X chromosome (Plath et al. 2003; Kohlmaier et al. 2004).

Taken together, these genetic studies suggest that PRC2 is unlikely to play an important role in the initiation of X inactivation and, furthermore, that it is not critical for maintenance of random $\mathrm{X}$ inactivation in embryonic tissues. Presumably, the participation of multiple epigenetic marks in random $\mathrm{X}$ inactivation, including $\mathrm{H} 3 \mathrm{~K} 9 \mathrm{me} 2$ and H4K20me1 and other unknown factors, may render the requirement for PRC2 less critical. However, PRC2 does seem to play an important role in the maintenance of imprinted $\mathrm{X}$ inactivation in extraembryonic tissues. Further insight into this has come from a recent study showing that the defect in maintenance of the inactive state is only found in differentiated $\mathrm{Eed}^{-/-}$trophoblast cells (Kalantry et al. 2006). Intriguingly, in undifferentiated $\mathrm{Eed}^{-/-}$trophoblast stem cells, many characteristics of the inactive X, such as Xist RNA coating, PRC1 and PRC2 proteins, and associated histone modifications, are no longer detectable, despite its transcriptional inactivity (Kalantry et al. 2006). The authors conclude that PcG complexes are not necessary to maintain transcriptional 
silencing of the inactive $\mathrm{X}$ chromosome in undifferentiated stem cells. Instead, PcG proteins could be involved in the cellular memory that prevents transcriptional activation of the inactive $\mathrm{X}$ during differentiation.

The exact mechanism underlying PRC2's role in maintaining inactivity of the $\mathrm{X}$ chromosome is unknown. Drawing on parallels with other systems, it is known that a subset of PRC2 complexes contain HDAC activity in human cells (van der Vlag and Otte 1999) and in Drosophila (Tie et al. 2001, 2003). Deacetylation of histones might therefore also participate in PRC2's action on the $\mathrm{X}$ chromosome. Consistent with this, the accumulation of PRC2 on the Xi occurs within a similar time window to $\mathrm{H} 4$ hypoacetylation, although $\mathrm{H} 3 \mathrm{~K} 9$ hypoacetylation seems to be a slightly earlier event (Heard et al. 2001; Chaumeil et al. 2002; Okamoto et al. 2004). Alternatively, the $\mathrm{H} 3 \mathrm{~K} 27 \mathrm{me} 3 \mathrm{mark}$ and/or other marks induced by PRC2 complexes (e.g., H1K26 methylation; Kuzmichev et al. 2004) may have a direct effect on chromatin accessibility or packaging. Yet another possibility, supported by substantial genetic and biochemical studies in different species, is that PRC2 leads to the recruitment of the PRC1 complex and that this performs the maintenance function. In vitro studies have shown that PRC1 may act at several levels to maintain silencing. These include inhibition of nucleosome remodeling mediated by SWI/SNF (Shao et al. 1999; Lavigne et al. 2004), induction of chromatin compaction (Francis et al. 2004; Lavigne et al. 2004), inhibition of transcription initiation (Dellino et al. 2004), and ubiquitinated H2A-mediated gene silencing (Wang et al. 2004).

Although PRC1 complex proteins and associated H2A ubiquitination appear to associate with the inactive $\mathrm{X}$ chromosome during both imprinted and random $\mathrm{X}$ inactivation (de Napoles et al. 2004; Fang et al. 2004; Plath et al. 2004), so far their exact role(s) in $\mathrm{X}$ inactivation remains unclear. Schoeftner et al. (2006) have recently shown that PRC1 recruitment by Xist RNA to the X chromosome is independent of gene silencing, similarly to PRC2. Mutant homozygous mice have been reported for some components of PRC1 such as Ring1A (del Mar Lorente et al. 2000), Ring1B (Voncken et al. 2003), Cbx2/M33 (Coré et al. 1997; Katoh-Fukui et al. 1998), Bmil (van der Lugt et al. 1994), Mel18 (Akasaka et al. 1996), Phc1 (Takihara et al. 1997), and Phc2 (Isono et al. 2005), which were shown to accumulate on the $\mathrm{Xi}$ in certain cell types. These mutants, except for Ring1B, which shows early embryonic lethality, show homeotic abnormalities consistent with the misregulation of Hox genes, although effects in the maintenance of $\mathrm{X}$ inactivation were not assessed. However, XX ES cells mutated for Ringl $a$ and Ring $1 b$ have been created, and although H2A ubiquitination in the inactive $\mathrm{X}$ is clearly disrupted, they do not show any obvious alteration in X-inactivation status (de Napoles et al. 2004). The probable redundancy between different PRC proteins and other epigenetic marks on the $\mathrm{X}$ chromosome may render determination of the functional importance of PRC1 proteins in X inactivation a difficult task. Further genetic studies will be required, involving multiple knockouts and careful analyses in different embryonic and extraembryonic lineages.

\section{Recruitment of PRC2 and PRC1 Complexes to the Inactive $\mathrm{X}$ Chromosome}

In Drosophila, the PRC2 complex is targeted to specific regions for repression via Polycomb response elements (PREs) (Bantignies and Cavalli 2006). In mammals, DNA sequences equivalent to PREs are still being sought. In the case of $\mathrm{X}$ inactivation, the recruitment of PRC2 appears to be a direct consequence of Xist RNA coating, which, as mentioned earlier, might suggest that Xist itself targets PRC2 to the $\mathrm{X}$ chromosome. However, it cannot be excluded that PRC2 is recruited as an immediate consequence of some chromosomal change induced by Xist RNA.

In the case of the PRC1 complex, its targeting to chromatin is thought to be at least partly dependent on the presence of PRC2-induced H3K27me3 in Drosophila. The Polycomb $(\mathrm{Pc})$ protein, which is a core component of PRC1, has been shown to bind to H3K27me3 with strong affinity (Fischle et al. 2003; Min et al. 2003), and this has thus been proposed as a mechanism through which the PRC2 complex could lead to the recruitment of PRC1. The domain of the Pc protein that appears to bind to the H3K27me3 mark is a conserved amino acid motif known as the chromodomain. In mammals there are five Pc homologs: Cbx2/M33/Mpc1, Cbx4/Mpc2, Cbx6, Cbx7, and $\mathrm{Cbx} 8 / \mathrm{Mpc} 3$. All of these, except $\mathrm{Cbx} 4$, have been shown to have a high affinity for H3K27me3 (Bernstein et al. 2006). We recently set out to address whether Pc proteins associate with the inactive $\mathrm{X}$ chromosome and to gain insight into the mechanism of their recruitment. Using female mouse ES cells, we were able to detect the presence of several of these Cbx proteins on the inactive $X$ chromosome (Bernstein et al. 2006). When fused to GFP, all Cbx proteins, except $\mathrm{Cbx} 4$, showed preferential accumulation on the $\mathrm{H} 3 \mathrm{~K} 27$ tri-Me enriched inactive X chromosome, following transient transfection in day 3-6 differentiating female ES cells. The accumulation was most striking for $\mathrm{Cbx} 7$ (Fig. 4). Using mutated forms of the $\mathrm{Cbx} 7$ protein, in which critical amino acids were changed within its chromodomain, we demonstrated that the association of $\mathrm{Cbx} 7$ with the inactive $\mathrm{X}$ is likely to be dependent on interactions between its chromodomain and H3K27me3. However, this interaction alone may not be sufficient for $\mathrm{Cbx} 7$ binding to the inactive $\mathrm{X}$ chromosome, as we showed that RNase treatment disrupts the Xchromosomal association of $\mathrm{Cbx} 7$ (Bernstein et al. 2006). This suggests that the $\mathrm{Cbx} 7$ protein is helped in its association with the $\mathrm{X}$ chromosome by an RNA entity, the nature of which remains to be defined. This could be reminiscent of previous in vitro findings showing that the chromodomain is capable of binding RNA molecules (Akhtar et al. 2000). Furthermore, several recent studies have implicated intergenic, noncoding RNA in Polycomb targeting or function (for review, see Ringrose et al. 2004). Obviously, Xist RNA is a tantalizing candidate for the RNA partner of $\mathrm{Cbx} 7$, but any association between Xist RNA and a Polycomb group protein remains to be demonstrated. Alternatively, the RNA involved could be of a totally different nature, similar to the RNA component associated with constitutive heterochromatin, that 

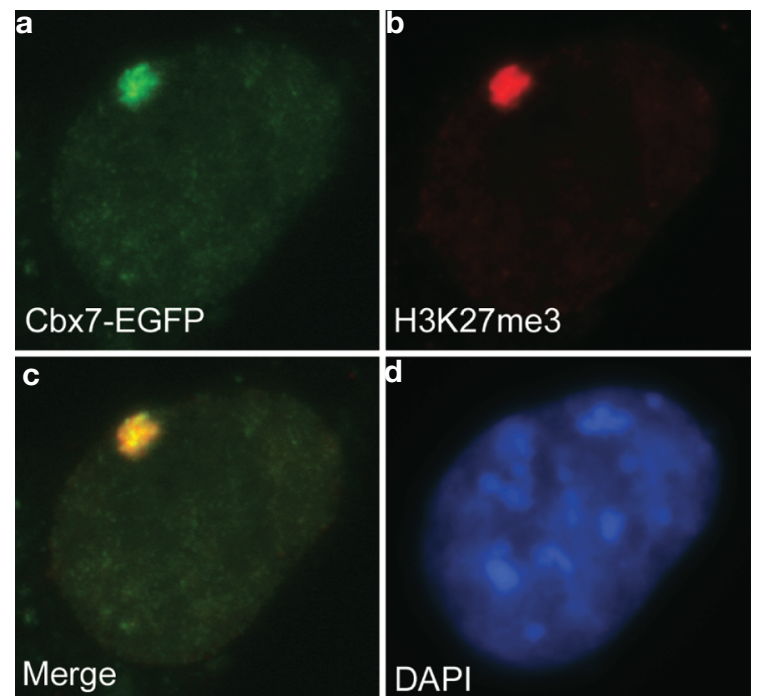

Figure 4. Preferential accumulation of Cbx7-GFP protein on the inactive $\mathrm{X}$ chromosome following transient transfection in female ES cells differentiated for more than 3 days. (a) Cbx7EGF. (b) Immunofluorescence for histone H3K27me2/3. (c) Merged image. (d) DAPI.

participates in HP1 binding to chromocenters in mouse cells (Maison et al. 2002). Our study suggests that the murine Pc homolog, $\mathrm{Cbx} 7$, in the PRC1 complex may require both $\mathrm{H} 3 \mathrm{~K} 27 \mathrm{me} 3$ and an RNA entity in order to be targeted to the X chromosome. Schoeftner et al. (2006) showed that Eed (and presumably the H3K27me3 mark) is also required for the recruitment of the canonical PRC1 proteins Mph1 and Mph2 by Xist RNA. However, they found that Eed is not required for recruitment of Ring $1 \mathrm{~b}$ and that this protein is recruited by Xist RNA and mediates ubiquitination of histone $\mathrm{H} 2 \mathrm{~A}$ in $\mathrm{Eed}^{-/-} \mathrm{ES}$ cells, which lack histone $\mathrm{H} 3 \mathrm{~K} 27 \mathrm{me} 3$. The implications of these findings are that PRC1 proteins may exist in more than one complex and may be recruited by independent mechanisms during $\mathrm{X}$ inactivation.

Taken together, these studies reveal the complexity of interactions and recruitment strategies that probably underlie targeting of the PRC1 complexes to the inactive $\mathrm{X}$ chromosome. The PRC2-induced H3K27me3 modification and one or more RNA entities, possibly including Xist itself, may be involved. Clearly, our understanding of the different protein and RNA partners involved in PcG targeting to the inactive $\mathrm{X}$ chromosome will require biochemical analyses in the future.

\section{CONCLUSION}

The X-inactivation process thus involves multiple actors, both RNA and protein. So far, Xist RNA has taken center stage. However, its partners have remained elusive and its mechanisms of action are likely to be complex. It appears to be multifunctional RNA acting at different levels during $\mathrm{X}$ inactivation, including its recently defined role in nuclear compartmentalization. The creation of a silent nuclear compartment by Xist RNA, independently of its gene silencing action, adds a new dimension to its function and opens up new concepts in X inactivation. Repeat elements on the X chromosome may be treated differently from genes, and their mechanisms of silencing, although both Xist-dependent, may differ. It is, of course, tempting to speculate that RNA interference may play a role in the silencing of repeats and/or genes, as has been shown in other organisms, but this possibility remains to be explored for $\mathrm{X}$ inactivation. The Polycomb group proteins also appear to be intimately linked to another level of Xist RNA function, although there is increasing evidence that multiple strategies may underlie their recruitment to the $\mathrm{X}$ chromosome. Furthermore, unraveling their exact role in maintaining the inactive state through genetic studies is likely to be complicated by the fact that numerous other epigenetic marks, many of which are still unknown, undoubtedly participate in this process. The future will require combined efforts using genetic, biochemical, and developmental approaches to identify these marks and define their roles.

\section{ACKNOWLEDGMENTS}

The authors apologize for any omissions in references that may have been made. We thank Julie Chaumeil for discussions and helpful comments on the manuscript. The work by our group described in this review was funded by the Human Frontier Science Program, the French Ministry of Research (ACI), the European Union's Network of Excellence (Epigenome), HEROIC (Highthroughput Epigenetic Regulatory Organization in Chromatin), an Integrated Project funded by the European Union under the 6th Framework Programme (LSHG-CT-2005-018883), the Schlumberger Foundation, and the Canceropole (IDF).

\section{REFERENCES}

Akhtar A., Zink D., and Becker P.B. 2000. Chromodomains are protein-RNA interaction modules. Nature 407: 405.

Akasaka T., Kanno M., Balling R., Mieza M.A., Taniguchi M., and Koseki H. 1996. A role for mel-18, a Polycomb grouprelated vertebrate gene, during the anteroposterior specification of the axial skeleton. Development 122: 1513.

Allaman-Pillet N., Djemai A., Bonny C., and Schorderet D.F. 2000. The $5^{\prime}$ repeat elements of the mouse Xist gene inhibit the transcription of X-linked genes. Gene Expr. 9: 93.

Bantignies F. and Cavalli G. 2006. Cellular memory and dynamic regulation of polycomb group proteins. Curr. Opin. Cell Biol. 18: 275.

Barr M.L. and Bertram E.G. 1949. A morphological distinction between neurones of the male and female and the behaviour of the nucleolar satellite during accelerated nucleoprotein synthesis. Nature 163: 676.

Bernstein E., Duncan E.M., Masui O., Gil J., Heard E., and Allis C.D. 2006. Mouse polycomb proteins bind differentially to methylated histone $\mathrm{H} 3$ and RNA and are enriched in facultative heterochromatin. Mol. Cell. Biol. 26: 2560.

Boggs B.A., Connors B., Sobel R.E., Chinault A.C., and Allis C.D. 1996. Reduced levels of histone H3 acetylation on the inactive X chromosome in human females. Chromosoma 105: 303.

Boggs B.A., Cheung P., Heard E., Spector D.L., Chinault A.C., and Allis C.D. 2002. Differentially methylated forms of histone $\mathrm{H} 3$ show unique association patterns with inactive human X chromosomes. Nat. Genet. 30: 73. 
Brown C.J. and Baldry S.E.L. 1996. Evidence that heteronuclear proteins interact with the XIST RNA in vitro. Somat. Cell Mol. Genet. 22: 403.

Brown C.J., Hendrich B.D., Rupert J.L., Lafreniere R.G., Xing Y., Lawrence J., and Willard H.F. 1992. The human XIST gene: Analysis of a $17 \mathrm{~kb}$ inactive X-specific RNA that contains conserved repeats and is highly localized within the nucleus. Cell 71: 527

Cao R. and Zhang Y. 2004. SUZ12 is required for both the histone methyltransferase activity and the silencing function of the EED-EZH2 complex. Mol. Cell 15: 57.

Cao R., Wang L., Wang H., Xia L., Erdjument-Bromage H., Tempst P., Jones R.S., and Zhang Y. 2002. Role of histone H3 lysine 27 methylation in Polycomb-group silencing. Science 298: 1039 .

Chaumeil J., Le Baccon P., Wutz A., and Heard E. 2006. A novel role for Xist RNA in the formation of a repressive nuclear compartment into which genes are recruited when silenced. Genes Dev. 20: 2223.

Chaumeil J., Okamoto I., Guggiari M., and Heard E. 2002. Integrated kinetics of $\mathrm{X}$ chromosome inactivation in differentiating embryonic stem cells. Cytogenet. Genome Res. 99: 75.

Clemson C.M., McNeil J.A., Willard H.F., and Lawrence J.B. 1996. XIST RNA paints the inactive X chromosome at interphase: Evidence for a novel RNA involved in nuclear/chromosome structure. J. Cell Biol. 132: 259.

Clemson C.M., Hall L.L., Byron M., McNeil J., and Lawrence J.B. 2006. The $\mathrm{X}$ chromosome is organized into a gene-rich outer rim and an internal core containing silenced nongenic sequences. Proc. Natl. Acad. Sci. 103: 7688

Coré N., Bel S., Gaunt S.J., Aurrand-Lions M., Pearce J., Fisher A., and Djabali M. 1997. Altered cellular proliferation and mesoderm patterning in Polycomb-M33-deficient mice. Development 124: 721.

Costanzi C., Stein P., Worrad D.M., Schultz R.M., and Pehrson J.R. 2000. Histone macroH2A1 is concentrated in the inactive $\mathrm{X}$ chromosome of female preimplantation mouse embryos. Development 127: 2283.

Czermin B., Melfi R., McCabe D., Seitz V., Imhof A., and Pirrotta V. 2002. Drosophila enhancer of Zeste/ESC complexes have a histone $\mathrm{H} 3$ methyltransferase activity that marks chromosomal Polycomb sites. Cell 111: 185.

Dellino G.I., Schwartz Y.B., Farkas G., McCabe D., Elgin S.C., and Pirrotta V. 2004. Polycomb silencing blocks transcription initiation. Mol. Cell 13: 887.

del Mar Lorente M., Marcos-Gutiérrez C., Pérez C., Schooriemmer J., Ramirez A., Magin T., and Vidal M. 2000. Loss- and gain-of-function mutations show a polycomb group function for Ring1A in mice. Development 127: 5093.

de Napoles M., Mermoud J.E., Wakao R., Tang Y.A., Endoh M., Appanah R., Nesterova T.B., Silva J., Otte A.P., Vidal M., et al. 2004. Polycomb group proteins Ring1A/B link ubiquitylation of histone $\mathrm{H} 2 \mathrm{~A}$ to heritable gene silencing and $\mathrm{X}$ inactivation. Dev. Cell 7: 663 .

Fackelmayer F.O. 2005. A stable proteinaceous structure in the territory of inactive X chromosomes. J. Biol. Chem. 280: 1720.

Fang J., Chen T., Chadwick B., Li E., and Zhang Y. 2004 Ring $1 \mathrm{~b}$-mediated $\mathrm{H} 2 \mathrm{~A}$ ubiquitination associates with inactive $\mathrm{X}$ chromosomes and is involved in initiation of $\mathrm{X}$ inactivation. J. Biol. Chem. 279: 52812.

Faust C., Schumacher A., Holdener B., and Magnuson T. 1995. The Eed mutation disrupts anterior mesoderm production in mice. Development 121: 273.

Filippova G.N., Cheng M.K., Moore J.M., Truong J.-P., Hu Y.J., Nguyen D.K., Tsuchiya K.D., and Disteche C.M. 2005. Boundaries between chromosomal domains of $\mathrm{X}$ inactivation and escape bind CTCF and lack $\mathrm{CpG}$ methylation during early development. Dev. Cell 8: 31 .

Fischle W., Wang Y., Jacobs S.A., Kim Y., Allis C.D., and Khorasanizadeh S. 2003. Molecular basis for the discrimination of repressive methyl-lysine marks in histone $\mathrm{H} 3$ by Polycomb and HP1 chromodomains. Genes Dev. 17: 1870.

Francis N.J., Kingston R.E., and Woodcock C.L. 2004
Chromatin compaction by a polycomb group protein complex. Science 306: 1574.

Gil J., Bernard D., and Peter G. 2005. Role of Polycomb group proteins in stem cell self-renewal and cancer. DNA Cell Biol. 24: 117

Heard E. 2004. Recent advances in X-chromosome inactivation. Curr. Opin. Cell Biol. 16: 247.

Heard E., Rougeulle C., Arnaud D., Avner P., Allis C.D., and Spector D.L. 2001. Methylation of histone H3 at Lys-9 is an early mark on the $\mathrm{X}$ chromosome during $\mathrm{X}$ inactivation. Cell 107: 727

Isono K., Fujimura Y., Shinga J., Yamaki M., O-Wang J., Takihara Y., Murahashi Y., Takada Y., Mizutani-Koseki Y., and Koseki H. 2005. Mammalian polyhomeotic homologs $\mathrm{Phc} 2$ and $\mathrm{Phc} 1$ act in synergy to mediate polycomb repression of Hox genes. Mol. Cell. Biol. 25: 6694.

Jeppesen P. and Turner B.M. 1993. The inactive X chromosome in female mammals is distinguished by a lack of histone $\mathrm{H} 4$ acetylation, a cytogenetic marker for gene expression. Cell 74: 281.

Kalantry S. and Magnuson T. 2006. The Polycomb group protein EED is dispensable for the initiation of random X-chromosome inactivation. PLoS Genet. 2: e66

Kalantry S., Mills K.C., Yee D., Otte A.P., Panning B., and Magnuson T. 2006. The Polycomb protein Eed protects the inactive $\mathrm{X}$-chromosome from differentiation-induced reactivation. Nat. Cell Biol. 8: 195.

Katoh-Fukui Y., Tsuchiya R., Shiroishi T., Nakahara Y., Hashimoto N., Noguchi K., and Higashinakagawa T. 1998. Male-to-female sex reversal in M33 mutant mice. Nature 393: 688 .

Kay G.F., Penny G.D., Patel D., Ashworth A., Brockdorff N., and Rastan S. 1993. Expression of Xist during mouse development suggests a role in the initiation of X chromosome inactivation. Cell 72: 171

Keohane A.M., O’Neill L.P., Belyaev N.D., Lavender J.S., and Turner B.M. 1996. X-inactivation and histone H4 acetylation in embryonic stem cells. Dev. Biol. 180: 618.

Kohlmaier A., Savarese F., Lachner M., Martens J., Jenuwein T., and Wutz A. 2004. A chromosomal memory triggered by Xist regulates histone methylation in $\mathrm{X}$ inactivation. PLoS Biol. 2: E171.

Kuzmichev A., Jenuwein T., Tempst P., and Reinberg D. 2004. Different EZH2-containing complexes target methylation of histone H1 or nucleosomal histone H3. Mol. Cell 14: 183.

Kuzmichev A., Nishioka K., Erdjument-Bromage H., Tempst P., and Reinberg D. 2002. Histone methyltransferase activity associated with a human multiprotein complex containing the Enhancer of Zeste protein. Genes Dev. 16: 2893.

Kuzmichev A., Margueron R., Vaquero A., Preissner T.S., Scher M., Kirmizis A., Ouyang X., Brockdorff N., AbateShen C., Farnham P., and Reinberg D. 2005. Composition and histone substrates of polycomb repressive group complexes change during cellular differentiation. Proc. Natl. Acad. Sci. 102: 1859.

Lavigne M., Francis N.J., King I.F., and Kingston R.E. 2004. Propagation of silencing; recruitment and repression of naive chromatin in trans by polycomb repressed chromatin. Mol. Cell 13: 415

Levine S.S., King I.F., and Kingston R.E. 2004. Division of labor in polycomb group repression. Trends Biochem. Sci. 29: 478.

Levine S.S., Weiss A., Erdjument-Bromage H., Shao Z., Tempst P., and Kingston R.E. 2002. The core of the polycomb repressive complex is compositionally and functionally conserved in flies and humans. Mol. Cell. Biol. 22: 6070 .

Lyon M.F. 1961. Gene action in the X-chromosome of the mouse (Mus musculus L.). Nature 190: 372.

Maison C., Bailly D., Peters A.H., Quivy J.P., Roche D., Taddei A., Lachner M., Jenuwein T., and Almouzni G. 2002. Higher-order structure in pericentric heterochromatin involves a distinct pattern of histone modification and an RNA component. Nat. Genet. 30: 329. 
Mak W., Baxter J., Silva J., Newall A.E., Otte A.P., and Brockdorff N. 2002. Mitotically stable association of polycomb group proteins eed and enx 1 with the inactive $\mathrm{x}$ chromosome in trophoblast stem cells. Curr. Biol. 12: 1016-1020.

Mak W., Nesterova T.B., de Napoles M., Appanah R., Yamanaka S., Otte A.P., and Brockdorff N. 2004. Reactivation of the paternal X chromosome in early mouse embryos. Science 303: 666.

Marahrens Y., Loring J., and Jaenisch R. 1998. Role of the Xist gene in $X$ chromosome choosing. Cell 92: 657.

Marahrens Y., Panning B., Dausman J., Strauss W., and Jaenisch R. 1997. Xist-deficient mice are defective in dosage compensation but not spermatogenesis. Genes Dev. 11: 156.

Mermoud J.E., Costanzi C., Pehrson J.R., and Brockdorff N. 1999. Histone macroH2A1.2 relocates to the inactive X chromosome after initiation and propagation of X-inactivation. $J$. Cell Biol. 147: 1399.

Mermoud J.E., Popova B., Peters A.H., Jenuwein T., and Brockdorff N. 2002. Histone H3 lysine 9 methylation occurs rapidly at the onset of random $\mathrm{X}$ chromosome inactivation. Curr. Biol. 12: 247.

Min J., Zhang Y., and Xu R.M. 2003. Structural basis for specific binding of Polycomb chromodomain to histone $\mathrm{H} 3$ methylated at Lys 27. Genes Dev. 17: 1823.

Müller J., Hart C.M., Francis N.J., Vargas M.L., Sengupta A., Wild B., Miller E.L., O'Connor M.B., Kingston R.E., and Simon J.A. 2002. Histone methyltransferase activity of a Drosophila Polycomb group repressor complex. Cell 111: 197208.

Ng J., Hart C.M., Morgan K., and Simon J.A. 2000. A Drosophila ESC-E(Z) protein complex is distinct from other polycomb group complexes and contains covalently modified ESC. Mol. Cell. Biol. 20: 3069.

Norris D.P., Brockdorff N., and Rastan S. 1991. Methylation status of CpG-rich islands on active and inactive mouse $\mathrm{X}$ chromosomes. Mamm. Genome 1: 78 .

O'Carroll D., Erhardt S., Pagani M., Barton S.C., Surani M.A., and Jenuwein T. 2001. The polycomb-group gene Ezh2 is required for early mouse development. Mol. Cell. Biol. 21: 4330.

Ohno S. and Hauschka TS. 1960. Allocycly of the X-chromosome in tumors and normal tissues. Cancer Res. 20: 541.

Okamoto I., Otte A.P., Allis C.D., Reinberg D., and Heard E. 2004. Epigenetic dynamics of imprinted $X$ inactivation during early mouse development. Science 303: 644.

Okamoto I., Arnaud D., Otte AP, Disteche C., Avner P., and Heard E. 2005. Evidence for de novo imprinted X-chromosome inactivation independent of meiotic inactivation in mice. Nature 438: 369.

Osborne C.S., Chakalova L., Brown K.E., Carter D., Horton A., Debrand E., Goyenechea B., Mitchell J.A., Lopes S., Reik W., and Fraser P. 2004. Active genes dynamically colocalize to shared sites of ongoing transcription. Nat. Genet. 36: 1065.

Otte A.P. and Kwaks T.H. 2003. Gene repression by Polycomb group protein complexes: A distinct complex for every occasion? Curr. Opin. Genet. Dev. 13: 448.

Pasini D., Bracken A.P., Jensen M.R., Lazzerini Denchi E., and Helin K. 2004. Suz12 is essential for mouse development and for EZH2 histone methyltransferase activity. $E M B O J$. 23: 4061.

Penny G.D., Kay G.F., Sheardown S.A., Rastan S., and Brockdorff N. 1996. The Xist gene is required in cis for X chromosome inactivation. Nature 379: 131.

Peters A.H.F.M., Mermoud J.E., O'Carroll D., Pagani M., Schweizer D., Brockdorff N., and Jenuwein T. 2002. Histone H3 lysine 9 methylation is an epigenetic imprint of facultative heterochromatin. Nat. Genet. 30: 77.

Plath K., Talbot D., Hamer K.M., Otte A.P., Yang T.P., Jaenisch R., and Panning B. 2004. Developmentally regulated alterations in Polycomb repressive complex 1 proteins on the inactive X chromosome. J. Cell Biol. 167: 1025.

Plath K., Fang J., Mlynarczyk-Evans S.K., Cao R., Worringer K.A., Wang H., de la Cruz C.C., Otte A.P., Panning B., and
Zhang Y. 2003. Role of histone H3 lysine 27 methylation in X inactivation. Science 300: 131.

Ringrose L. and Paro R. 2004. Epigenetic regulation of cellular memory by the Polycomb and Trithorax group proteins. Annu. Rev. Genet. 38: 413.

Ringrose L., Ehret H., and Paro R. 2004. Distinct contributions of histone H3 lysine 9 and 27 methylation to locus-specific stability of Polycomb complexes. Mol. Cell 16: 641.

Rougeulle C., Chaumeil J., Sarma K., Allis C.D., Reinberg D., Avner P., and Heard E. 2004. Differential histone H3 Lys-9 and Lys-27 methylation profiles on the X chromosome. Mol. Cell. Biol. 24: 5475.

Saurin A.J., Shao Z., Erdjument-Bromage H., Tempst P., and Kingston R.E. 2001. A Drosophila Polycomb group complex includes Zeste and dTAFII proteins. Nature 412: 655.

Schoeftner S., Sengupta A.K., Kubicek S., Mechtler K., Spahn L., Koseki H., Jenuwein T., and Wutz A. 2006 Recruitment of $\mathrm{PRC} 1$ function at the initiation of $\mathrm{X}$ inactivation independent of PRC2 and silencing. EMBO J. 25: 3110.

Shao Z., Raible F., Mollaaghababa R., Guyon J.R., Wu C.T., Bender W., and Kingston R.E. 1999. Stabilization of chromatin structure by PRC1, a Polycomb complex. Cell 98: 37.

Silva J., Mak W., Zvetkova I., Appanah R., Nesterova T.B., Webster Z., Peters A.H., Jenuwein T., Otte A.P., and Brockdorff N. 2003. Establishment of histone h3 methylation on the inactive $\mathrm{X}$ chromosome requires transient recruitment of Eed-Enx1 polycomb group complexes. Dev. Cell 4: 481.

Tada T., Obata Y., Tada M., Goto Y., Nakatsuji N., Tan S., Kono T., and Takagi N. 2000. Imprint switching for non-random Xchromosome inactivation during mouse oocyte growth. Development 127: 3101.

Takagi N., Sugawara O., and Sasaki M. 1982. Regional and temporal changes in the pattern of X-chromosome replication during the early post-implantation development of the female mouse. Chromosoma 85: 275.

Takihara Y., Tomotsune D., Shirai M., Katoh-Fukui Y., Nishii K., Motaleb M.A., Nomura M., Tsuchiya R., Fujita Y., Shibata Y., et al. 1997. Targeted disruption of the mouse homolog of the Drosophila polyhomeotic gene leads to altered anteroposterior patterning and neural crest defects. Development 124: 3673.

Tie F., Furuyama T., Prasad-Sinha J., Jane E., and Harte P.J. 2001. The Drosophila Polycomb Group proteins ESC and E(Z) are present in a complex containing the histone-binding protein p55 and the histone deacetylase RPD3. Development 128: 275.

Tie F., Prasad-Sinha J., Birve A., Rasmuson-Lestander A., and Harte P.J. 2003. A 1-megadalton ESC/E(Z) complex from Drosophila that contains polycomblike and RPD3. Mol. Cell. Biol. 23: 3352.

van der Vlag J. and Otte A.P. 1999. Transcriptional repression mediated by the human polycomb-group protein EED involves histone deacetylation. Nat. Genet. 23: 474.

van der Lugt N.M., Domen J., Linders K., van Roon M., RobanusMaandag E., te Riele H., van der Valk M., Deschamps J., Sofroniew M., van Lohuizen M., et al. 1994. Posterior transformation, neurological abnormalities, and severe hematopoietic defects in mice with a targeted deletion of the bmi-1 protooncogene. Genes Dev. 8: 757.

Voncken J.W., Roelen B.A., Roefs M., de Vries S., Verhoeven E., Marino S., Deschamps J., and van Lohuizen M. 2003. Rnf2 (Ring1b) deficiency causes gastrulation arrest and cell cycle inhibition. Proc. Natl. Acad. Sci. 100: 2468.

Wang H., Wang L., Erdjument-Bromage H., Vidal M., Tempst P., Jones R.S., and Zhang Y. 2004. Role of histone H2A ubiquitination in Polycomb silencing. Nature 431: 873.

Wang J., Mager J., Chen Y., Schneider E., Cross J.C., Nagy A., and Magnuson T. 2001. Imprinted X inactivation maintained by a mouse Polycomb group gene. Nat. Genet. 28: 371 .

Wutz A. and Jaenisch R.A. 2000. A shift from reversible to irreversible $\mathrm{X}$ inactivation is triggered during ES cell differenciation. Mol. Cell 5: 695.

Wutz A., Rasmussen T.P., and Jaenisch R.A. 2002. Chromosomal silencing and chromosomal localization are mediated by different domains of Xist RNA. Nat. Genet. 30: 167. 


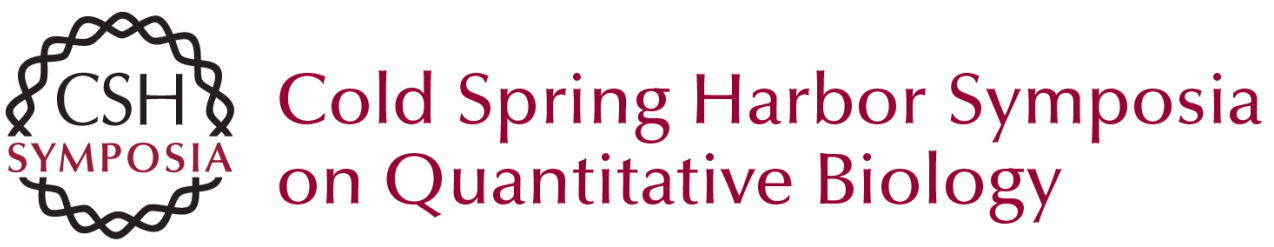

\section{RNA and Protein Actors in X-Chromosome Inactivation}

O. MASUI and E. HEARD

Cold Spring Harb Symp Quant Biol 2006 71: 419-428

Access the most recent version at doi:10.1101/sqb.2006.71.058

References This article cites 87 articles, 36 of which can be accessed free at: http://symposium.cshlp.org/content/71/419.full.html\#ref-list-1

\section{License}

Email Alerting Receive free email alerts when new articles cite this article - sign up in Service the box at the top right corner of the article or click here. 